\title{
Morphology of the retina in the freshwater fish Metynnis roosevelti Eigenmann (Characidae, Serrasalminae) and the effects of monochromatic red light
}

\author{
Lucélia Donatti ${ }^{1}$ \\ Edith Fanta ${ }^{2}$
}

\begin{abstract}
The retina of Metynnis roosevelti Eigenmann, 1915, a very active freshwater fish, was investigated by light and electron microscopy and was found to have a complex neuronal structure that allows rapid responses of visual stimuli. Retina photoreceptors are double cones, single long cones, single short cones and rods. Cone inner segments are arranged as mosaics. The outer nuclear layer contains small nuclei of twin cones, long and wide nuclei of long single cones, spherical large nuclei of short cones, and small dense nuclei of rods. Horizontal, amacrine, bipolar and ganglion neurones are responsible for connections and integration between photoreceptor cells and afferent neurones. The pigmented epithelium comprises a single layer of cylindrical cells each with elongated nuclei, mitochondria at the basal region, and melanin grains that can migrate inside long cell processes, depending on light intensity. In darkness, pigment is concentrated in the basal region of the cells and in daylight it is concentrated in the processes, surrounding and protecting the outer segments of photoreceptors. When exposed experimentally to monochromatic red light, expansion of melanin pigments was provoked at the beginning of light period, followed by their withdrawal after exposure to long wave lengths. No active movements of cones or rods were observed. Considerable renewal of photoreceptor membrane discs occurred after one week in red light, caused by higher level of activation of rods to allow the fish to see in relative darkness. Metynnis roosevelti is a native fish from Brazilian tropical and sub-tropical regions. More recently trials were made to use it in fish cultures in different regions of the country. Its capacity to adjust to different photic environments facilitates for rearing in varied environments.

KEY WORDS. Fish, retina, morphology, red light
\end{abstract}

Fish are influenced by many environmental factors one of the most important of which is light. Light either directly or indirectly affects vital processes such as reproduction, development, migrations, swimming activities, search for food, territorial defence, and detection of predators (NICOL 1963; LEVINE \& MACNICHOL JR. 1982; TEYKE \& SCHAERER 1994; Collin 1993; FANTA et al. 1991, 1994).

1) Departamento de Ciências Biológicas, Universidade Estadual do Centro Oeste. Guarapuava, Paraná, Brasil.

2) Correspondence address: Departamento de Biologia Celular, Universidade Federal do Paraná. Caixa Postal 19031, 81531-970 Curitiba, Paraná, Brasil.

E-mail: fantaf@ineparnet.com.br 
Fishes show morphological, functional, and evolutionary adaptations to the various light wave lengths that occur in their natural habitats. Complex eyes became organised and nervous and epithelial cells acquired specialisation to improve their capacity to distinguish shape, size and movements of external objects, and to react to the intensity and quality of light. Besides that, other photosensitive sites like skin, vertebral column, brain and pineal complex also evolved in fish (TEYKE \& SCHAERER 1994; OMURA \& OGURI 1991; SAMEJIMA et al. 1991). Functional and structural variability is related to environmental factors, evolution, and genetics (EASTMAN 1988; 1993; MENEZES et al. 1981; FANTA et al. 1994; PANKHURST \& MONTGOMERY 1989), to feeding strategies, activity patterns, inter- and intraspecific relations (FANTA et al. 1994; ZAUNREITER et al. 1991; WillLIAMSON \& KEAST 1988; HAIRSTON JR. et al. 1982; PogGio \& Koch 1987; MENEZES et al. 1981) and to the quality (wave length or colour) and intensity (quantity of energy) of light (LEVINE \& MACNICHOL JR. 1982; WHEELER 1979, 1982; LOUKASHKIN \& GRANT 1959; FANTA 1995; AllEN \& FERNALD 1985).

In their natural habitat, fish encounter long wave length light, corresponding to red light. Studies on the influence of red light in teleostean fishes revealed that this wave length comes close to a sensation of darkness and can be related to a number of specific reactions such as: escape reactions, coupling (WHEELER 1982), adaptability to darkness (WHEELER 1979), dispersal of fish schools (LOUKASHKIN \& GRANT 1959), diminishing of motor activities, and increase in aggressiveness (FANTA 1995); and loss of visual acuity (WHEELER 1979; LEVINE \& MACNICHOL JR. 1982; NICOL 1963).

The penetration of red light in the aquatic environment depends on the chemical, biological, and physical characteristics of the water. Thus, in salt water, at shallow to medium depths, red light is detectable by many species of teleosts, but fish that live in deeper waters where red light doesn't penetrate, do not have visual pigments that absorb red light. On the other hand in shallow freshwater, the majority of teleosts have the ability to detect long wave length light and are adapted to perceive rapid changes of light from long to short wave lengths (LEVINE \& MACNICHOL JR.1982).

Metynnis roosevelti Eigenmann, 1915 (Characidae, Serrasalminae) is a fish that shows high levels of activity in shallow, continental freshwater, in tropical and subtropical regions of Brazil where they swim for considerable distances (MACHADO-AlLisON 1983; GÉRY \& FRANCE 1979). Consequently they face a highly variable photic environment. This study was carried out not only to describe the morphology of the retina but also to investigate the morpho-functional mechanisms of the retina that are activated by experimental exposure to monochromatic red light.

\section{MATERIAL AND METHODS}

Specimens of one brood of Metynnis roosevelti were obtained from commercial dealers. They were kept in the laboratory for one month and acclimated under controlled environmental conditions in a grey shielded aquarium where they were exposed daily for eight hours to daylight. 
Sixty four adult fish of mean total length $4.5 \pm 1.0 \mathrm{~cm}$ and mean weight $3.0 \pm 0.5$ $\mathrm{g}$ were selected for the tests on the effect of exposure to monochromatic red light in two $128 \mathrm{~L}$ aquariums: the experimental fishes were illuminated with upper red light and the control fishes with upper daylight. The experimental aquarium was lined with red except for the frontal wall that was protected by a red shield with an observation slit (FANTA 1995). The peak of absorbancy of the red environment was $500 \mathrm{~nm}$. The control aquarium was lined with grey, being the observation shield also grey, a colour considered as neutral. The upper red light was obtained by a daylight lamp covered by a red filter being the same kind of lamp used for the control, but without red filter. The photoperiod was 8 hours of daylight/ 16 hours darkness and the light intensity during the diurnal period was $87 \pm 5$ lux in both, the control and the experimental aquarium. All other abiotic conditions were maintained constant in the control and the experimental aquarium, being the quality of the incident light and the background colour the only variables: the temperature was maintained at $25.5 \pm 0.5^{\circ} \mathrm{C}$, the $\mathrm{pH}$ in $7.2 \pm 0.2$ and the feeding time was one hour before the start of the light period.

The behaviour of experimental and control fish was observed by the direct method (FANTA 1995).

Samples for morphological studies of the retina were obtained at the start of the light period, considered as the start of the experiment (To) and after 30 minutes, $2,4,8,24,48$ and 168 hours of exposure to red light. In each test and at all times the retina of two experimental and two control fish were collected. The eyes were extracted, the supporting muscles and the optical nerve being maintained. One of the muscles was always tagged with a red thread, to help future orientation during embedding. The experimental fish were maintained in red light during the dissection procedures, until the retina has been placed in the fixative, while the control animals were manipulated under daylight.

For histology the entire eyes were fixed in Bouin's fluid and in Gendre for six hours. After routine dehydration they were embedded with orientation in Paraplast plus ${ }^{(}$. Three micrometers sections were stained with Haematoxilyn and Eosin (BÜCHERL 1962), Heidenhein's iron Haematoxilyn (CulLING et al. 1985), Mallory's Trichrome, Schiff Periodic Acid (CLARK 1981) and Novelli or Acid Fuchsin - Light Green (BEÇAK \& VANRELL 1970), and photographed in a Olympus photomicroscope PM 10 AD.

For transmission electron microscopy (TEM) the right eyes were fixed in 2.5 $\%$ glutaraldehyde in $0.4 \mathrm{M}$ Sörensen's phosphate buffer $\mathrm{pH} 7.2$ at $4^{\circ} \mathrm{C}$ for 2 hours. Post-fixed in $2 \% \mathrm{OsO}_{4}$, contrasted in $2 \%$ uranyl acetate or $2 \%$ tannic acid, the samples were embedded in Epon-812 (LUFT 1961). The ultra-thin sections were stained in an aqueous solution of $2 \%$ uranyl acetate (WATSON 1958) and a solution of lead nitrate (REYNOLDS 1963). Microphotographs were obtained in a JEOL TEM 1200 EX55 and a JEOL TEM-100 CX II.

For scanning electron microscopy (SEM) the left eyes were fixed in $3 \%$ glutaraldehyde, buffered in $0.2 \mathrm{M}$ cacodylate $\mathrm{pH} 7.2$ at $4^{\circ} \mathrm{C}$ for 24 hours. The critical point was obtained with $\mathrm{CO}_{2}$ in a Balzers CPD- 010 and coated with gold in a Balzers SCD-030. Microphotographs were obtained in a SEM Philips 505. 


\section{RESULTS}

In the aquariums $M$. roosevelti showed some behavioural patterns. They are organised in groups with a shoal-like swimming behaviour and while swimming and while resting they keep a constant distance between the individuals of the group. They are not territorial fish and show low levels of aggressiveness. When resting they remain preferentially close to the substrate, the body parallel to its surface or in an angle of $45^{\circ}$ with the tail higher than the head.

Feeding is preferentially close to the surface. The food is immediately detected when it reaches the water. After food detection, $M$. roosevelti perform fast swimming movements towards the surface. After food ingestion, they return immediately to their original place. The feeding movements of one fish in the group are recognised by the others inducing their feeding movements.

The head of $M$. roosevelti is laterally compressed and the eyes occupy a position on the mid line of each side of the fish head (Figs 1, 2b). The mean intra ocular distance was $0.6 \mathrm{~cm}( \pm 0.2 \mathrm{~cm})$ corresponding to $30-35 \%$ of the head length and the mean diameter of the eye was $0.5 \mathrm{~cm}$. Each eye is located in an orbit and supported by 6 extrinsic ocular muscles (Fig. 2a) that allow the eyes to move downwards (Fig. 2b), increasing the fish visual field.

The eye of M. roosevelti is almost spherical and has three concentric layers: (I) an outer, fibrous, whitish sclera with dense connective tissue and hyaline cartilage, continuous with a transparent cornea at the anterior region; (II) a choroid with loose connective tissue, supplied by blood vessels, and coloured dark brown due to the presence of melanocytes; (III) a retina consisting of two basic layers, the outer, pigmented epithelium and the inner, neural retina that contains the photoreceptors (Fig. 3).

\section{Morphology of the retina of Metynnis roosevelti}

The retina of $M$. roosevelti is composed of two layers: the pigmented epithelium and the neural retina. Four groups of cells were found in the neural retina: (I) photoreceptors, (II) conducting neurones, (III) association neurones and (IV) supporting and neuroglial cells. The arrangement of nuclei and processes of each of these cell types give the histological effect of 10 layers in the retina: pigment epithelium, layer of cones and rods or photoreceptor cells, outer limiting membrane, outer nuclear layer, outer plexiform layer, inner nuclear layer, inner plexiform layer, ganglion cell layer, layer of optic nerve fibres, and inner limiting membrane (Fig. $4 a)$. This structure is complex because some of the neuronal cells extend through many different layers.

The relative thickness of the retina and of each layer varies with the region of the eye: the retina is thicker laterally and thinner at the posterior region of the eye, close to the exit of the optical nerve (Fig. 5). The lateral region presents thinner optical fibres layer, but a thicker cones and rods layer with the extensions of the pigment epithelial cells, thicker inner nuclear layer and inner plexiform layer when compared to the posterior region. The optical nerve formed by afferent fibres of the retina exits the eye at the posterior region at the inferior right quarter of the right eye and the inferior left quarter of the left eye (Figs 2, 3). 

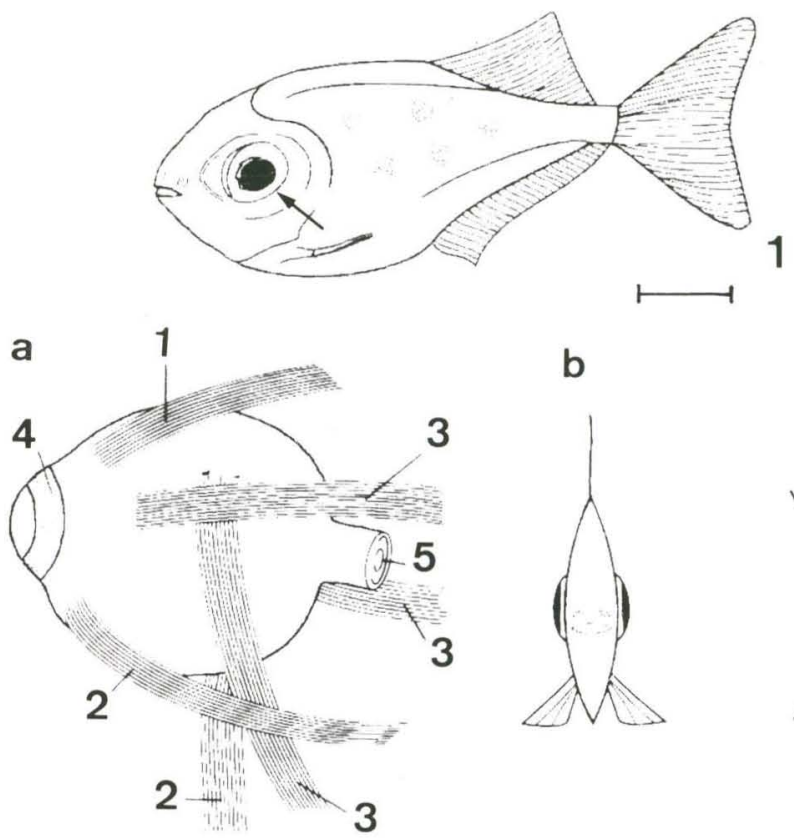

b
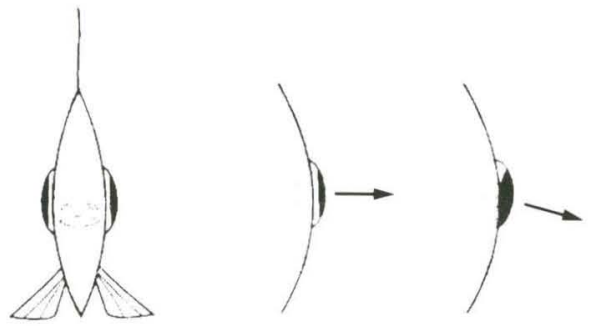

2

Figs 1-2. Metynnis roosevelti. (1) Notice the shape of the body and the position and proportional size of the eyes (arrow). Scale bar $0.5 \mathrm{~cm}$; (2a) eye globe showing the position of the extrinsic muscles: (1) superior muscle; (2) inferior muscles; (3) lateral muscles; (4) lens; (5) optical nerve; (b) frontal view, notice the lateral position of the eyes and their movements looking sidewards and downwards (arrows).

\section{Photoreceptors}

The retina contains two basic types of photoreceptors: cones and rods. Cones and rods are elongated highly specialised nervous cells, showing distinct regions: a cylindrical thin and long outer segment replenished by membrane discs; a short connecting stalk; an inner segment containing the main organelles that are responsible for the cell metabolism; an outer fibre that connects this part of the cell with the nuclear region, followed by an inner fibre region that ends with a synaptic region (Figs $4 \mathrm{c}, 6$ ). These structures are common to both photosensorial cells but their shape, size, and function are different in cones and rods.

Cones: Cones may be differentiated into single and double cones (Figs 4c-d, 6, 7a). Double cones are symmetrical, with two halves of the inner segment partly fused, of same shape, unequal in length, with the same affinity for colour (Figs $4 \mathrm{~b}$, $6,8)$. Some double cones show the two halves of the inner segment slightly twisted. Their nuclei are elongated and lie immediately under the outer limiting membrane, in the outer nuclear layer. The cell extensions reach the outer plexiform layer. They end with a pedicle with lateral extensions that make synaptic connections with other neurones. 


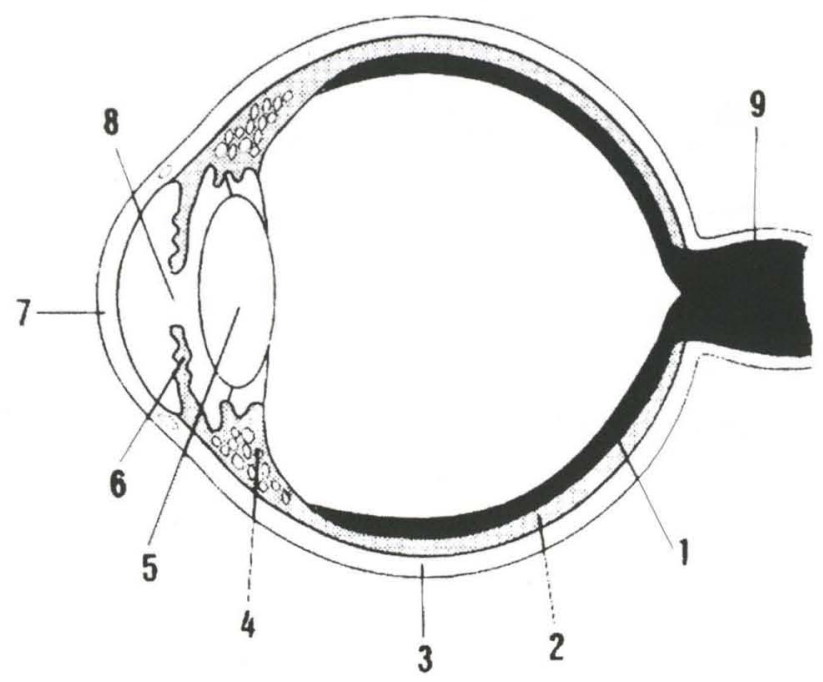

Fig. 3. Schematic representation of the structures of the eye of Metynnis roosevelti seen in a longitudinal median section. (1) retina; (2) choroid; (3) sclera; (4) ciliary body; (5) lens; (6) iris; (7) cornea; (8) pupil; (9) optical nerve.

The single cones are classified according to the size and shape of their inner segments in single long cones and single short cones (Figs 4b, 6, 8). The single long cone has a large inner segment of similar size and shape as one half of the double cone but stronger affinity for histological stains. The nucleus is large, elongated, and its outer part lies slightly above the outer limiting membrane (Figs 4c-d, 6, 7c). The outer fibre is enlarged showing lateral fins at the level of the outer limiting membrane that make connections with the Müller's supporting cell (Figs 4c, 6).

The inner segment of the single short cones is half the size of the inner segment of the long single cones. The nuclei are spherical and as large as the inner segment (Figs $4 \mathrm{c}, 6$ ), and placed immediately under the outer limiting membrane.

The outer segments of double and single cones are thin structures extending from the outer end of the internal segment of each cone towards the pigmented epithelium. They are partially covered by the melanin pigments contained in the extensions of the pigmented epithelial cells that surround them (Figs 4a-c, 7a). The external segment consists of a series of parallel discs lined by double membranes. The internal part of the discs is not continuous with the cellular medium (Fig. 7b). All discs are continuous with the outer segment plasma membrane at one side and continuous with the extracellular medium at the other. Calyceal processes extend from the distal part of the internal segment and surround the base of the external segment (Fig. 7a). 

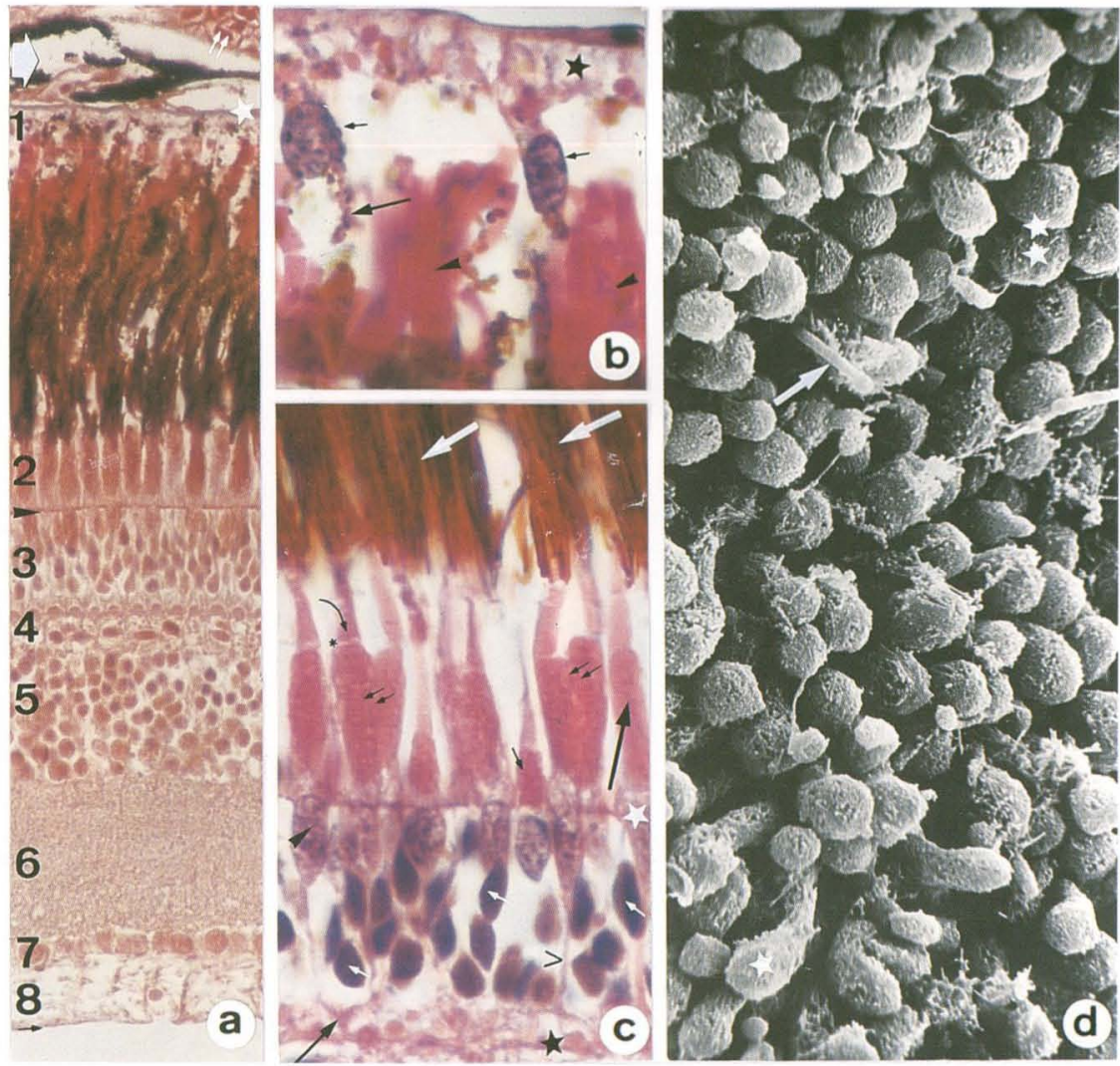

Fig. 4. (a) Section of the retina of Metynnis roosevelti showing the arrangement of cells and structural features that result in 10 layers: pigmented epithelium (1); layer of cones and rods (2); outer limiting membrane (arrow head); outer nuclear layer (3); outer plexiform layer (4); inner nuclear layer (5); inner plexiform layer (6); layer of ganglion cells (7); nerve fibre layer (8); inner limiting membrane (arrow). The figure also shows the choroid with pigment (white arrow); Bruch's membrane (star), blood vessels (small double arrow) (Mallory's triple stain). (b) Detail of pigment epithelium cells with basal part of the cell (star), nucleus (small arrow), extensions with pigment grains (long arrow); tip of outer segments of cones and rods (arrow head) (H.E.). (c) Detail of cones with outer segments of twin or double cones (double arrow); single long cones (long arrow); single short cones (small arrow); their outer segments (curved arrow); connecting stalk (small star); inner fibre (open arrow head); pedicle (arrow); cone nucleus (arrow head); rod nucleus (small white arrow); outer pelxiform layer (black star); connecting neurones (arrow); pigment epithelium cells extensions (white arrows); outer limiting membrane (white star) (H.E.). (d) Surface view of cones and rods showing double cones (double star); single cones (star); inner segments and outer segments (arrow) of rods (SEM).

The different cones in the retina are arranged regularly as a mosaic (Fig. 8). Each unit of the mosaic consists of four double cones surrounding a single cone and each single cone is separated from the neighbour single cone by a double cone. The 


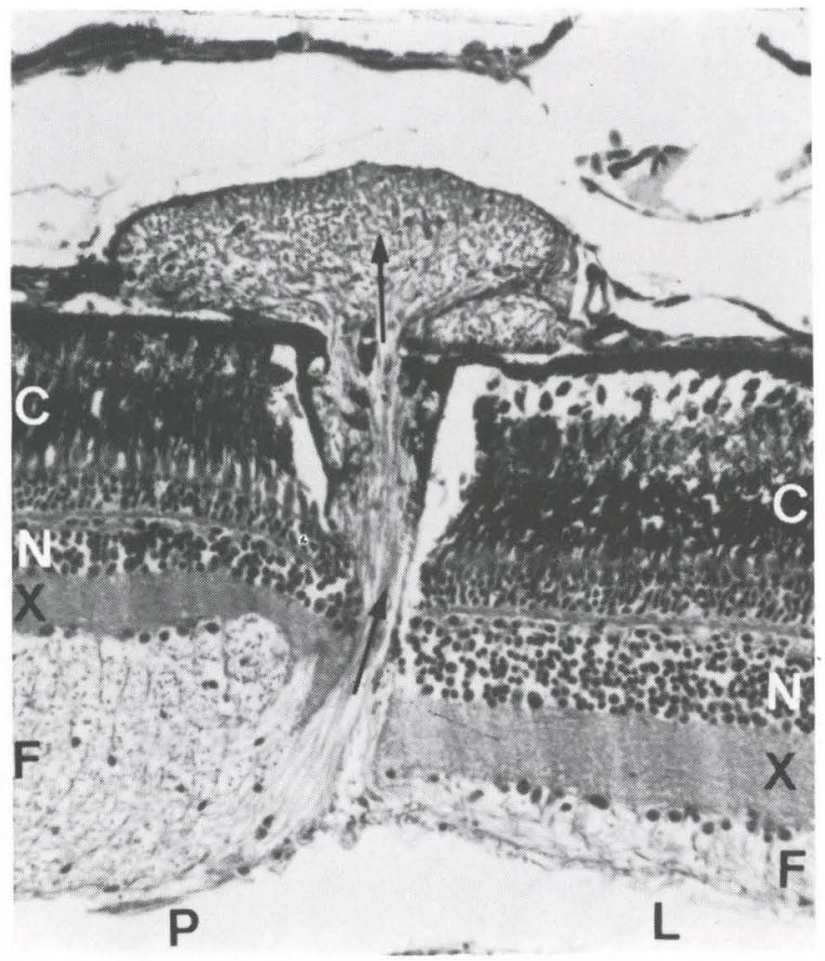

Fig. 5. Section of Metynnis roosevelti retina showing the region of the exit of the optical nerve (arrow) and the differences between lateral $(L)$ and posterior $(P)$ regions. $(C)$ cones and rods layer and extensions of pigmented epithelium cells; $(N)$ inner nuclear layer; $(X)$ inner plexiform layer; $(F)$ layer of nerve fibres. Notice the partial detachment of the pigment epithelium from the cones and rods layer, a common effect of the manipulation of the retina. (Heidenhein's iron Haematoxylin).

arrangement looks like a sequence of equal sided parallelograms of two types: with right angles or with angles of $60^{\circ}$ and $120^{\circ}$ (Fig. 8b).

Rods: The rods of $M$. roosevelti are thinner and longer cells than the cones (Figs 6,9a) and show uniform shape and size of inner and outer segments. The outer segments are slender structures, fragile and cylindrical, that reach the pigment epithelial cells, being mostly surrounded by its extensions and protected from excessive light incidence by the pigment grains (Figs 4b, 12a). The ultrastructure of rods outer segment is similar to that of the cones, showing piles of membrane discs. The discs are surrounded by double membranes. Most of them are of the same diameter as the outer segment, but some being smaller (Fig. 9c). They are not continuous with the outer segment plasma membrane but the cell membranes of neighbour outer segments are connected at several portions, seeming to be continuous (Fig. 9c-d). The inner segments are rich in mitochondria concentrated close to the stalk (Fig. 9b). The nuclei of the rods are placed in five different levels, from 


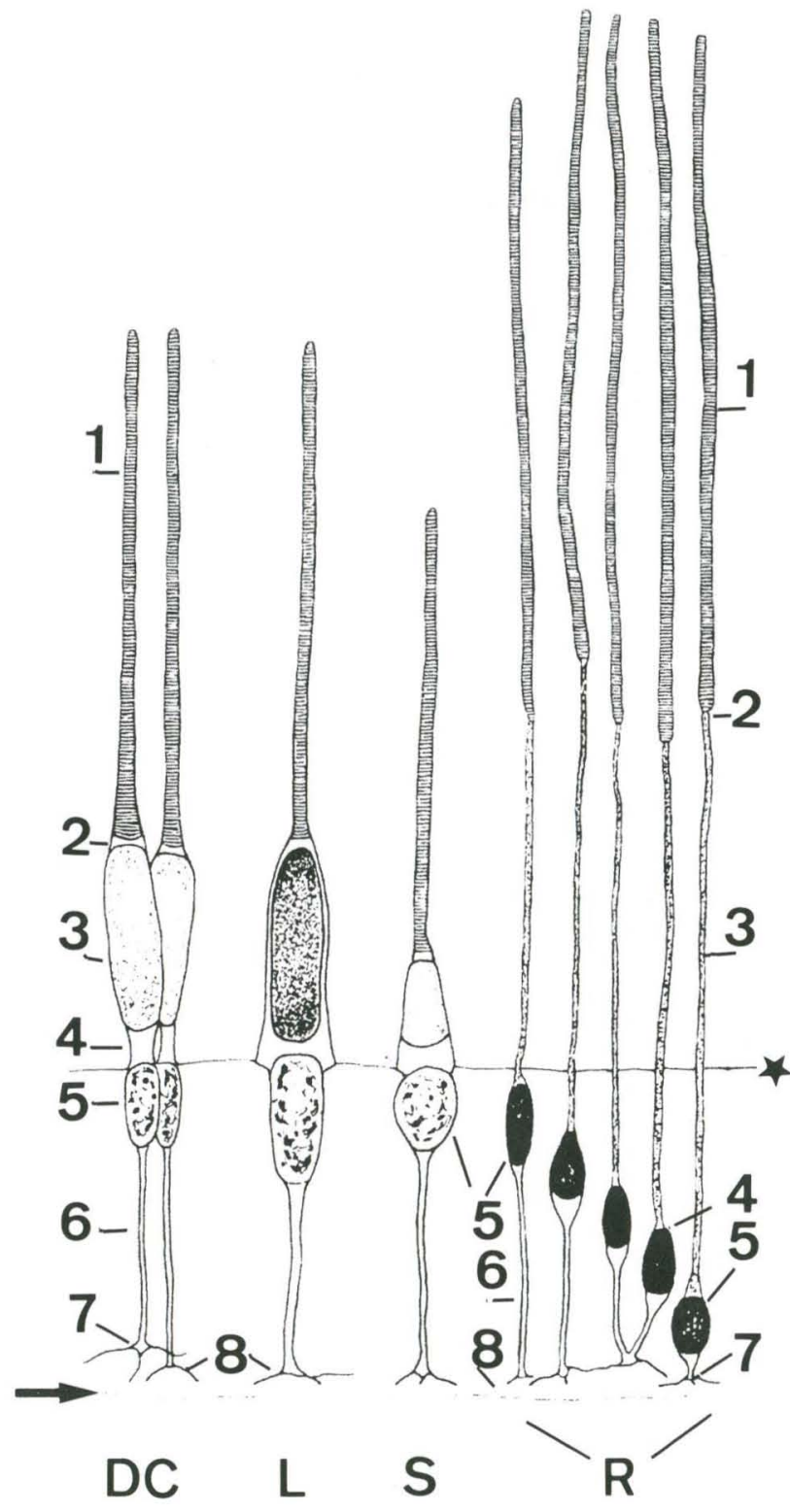

Fig. 6. Schematic representation of the cones and rods types: double cone (DC); long single cone $(L)$; short single cone $(S)$; rods $(R)$. The celular regions are outer segment with membrane discs (1); stalk (2); inner segment (3); outer fibre (4); nucleus (5); inner fibre (6); pedicle (7); extensions (8). Notice the relation of the photoreceptors to the outer limiting membrane (star) and the outer plexiform layer (arrow). 

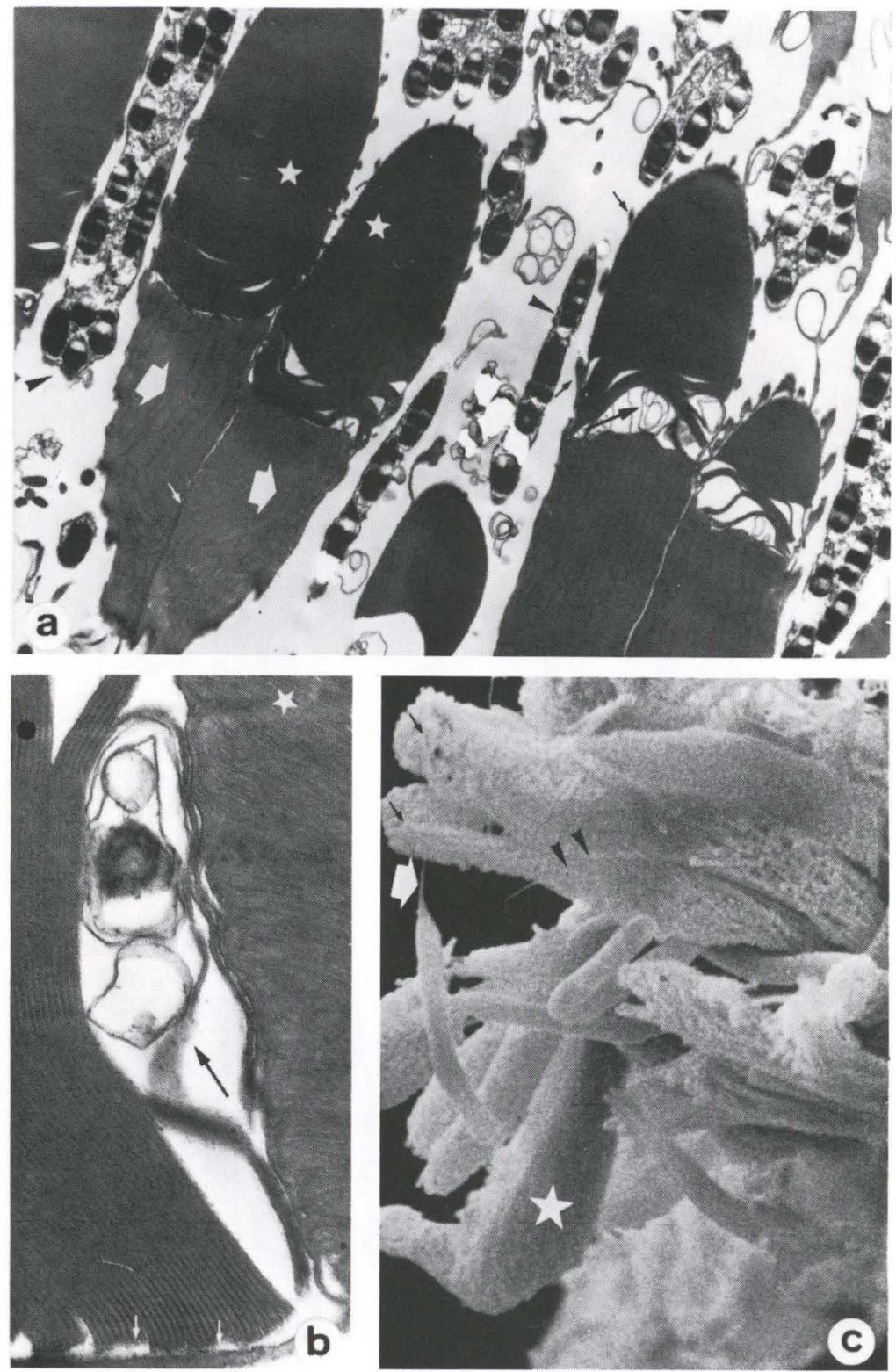

Fig. 7. (a) Double cones of Metynnis roosevelti with outer segment(star) surrounded by pigmented epithelium extensions (arrow head) containing melanin grains, calyceal processes (small arrow), stalk (arrow) and inner segment (wide arrow) (TEM). (b) Detail of stalk (arrow) between outer (bullet) and inner segment (star). Notice the membrane discs that are continuous with the extracellular space (small arrow) (TEM). (c) Double cones fused inner segments (arrow head), outer segments (small arrow), a single cone (star) and rods (large arrow) (SEM). 

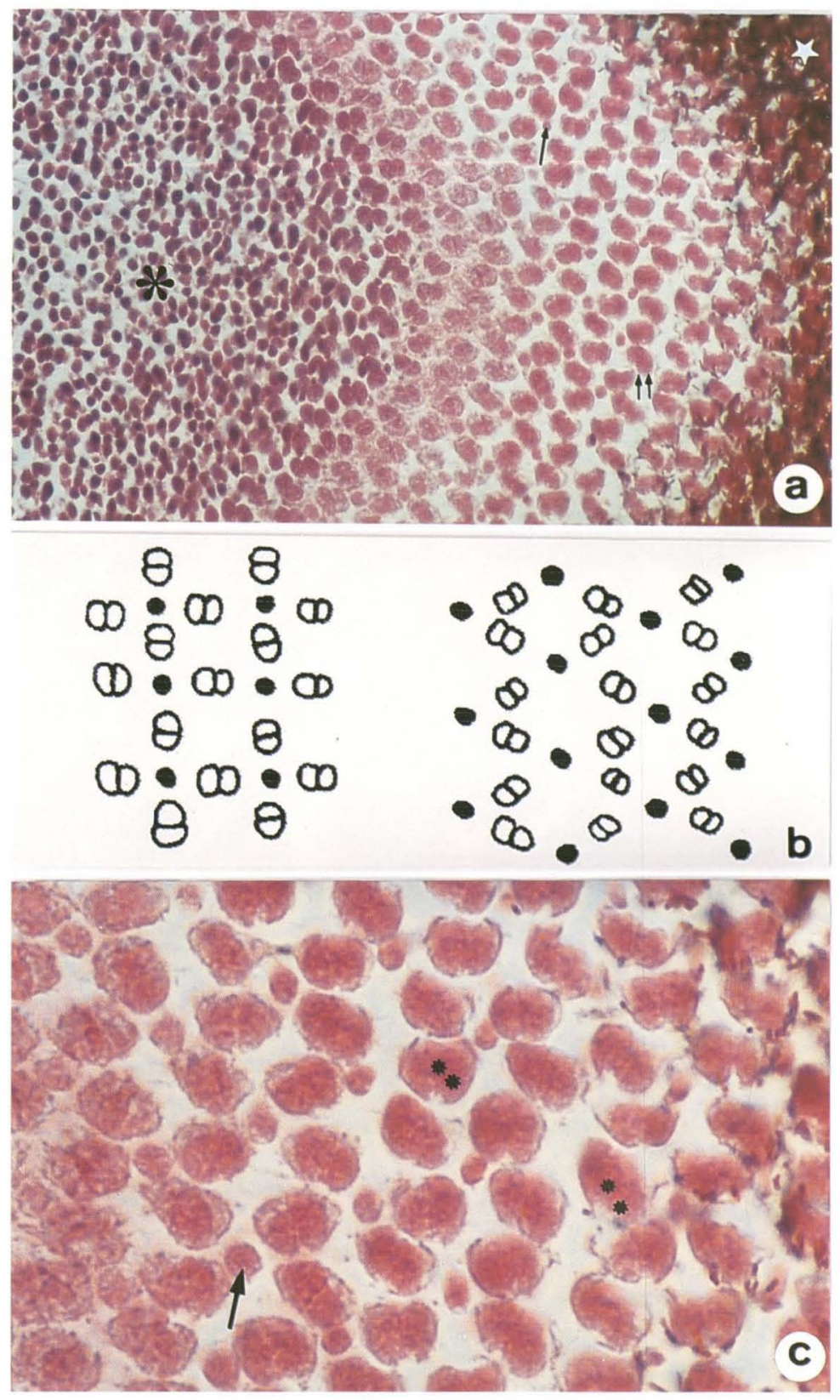

Fig. 8. (a) Mosaic arrangement of internal segments of cones in the retina of Metynnis roosevelti: double cones (double arrow) surround single cones (arrow). Pigmented epithelium (white star) and nuclear layer (black star) are sectioned horizontally. (H.E.). (b) Schematic representation of the parallelograms of double cones (white) and single long cones (black) in the retina. (c) Detail of double cones (double star) and single cones (arrow) arrangement. The diameter of cones will depend on the level and direction of the section (H.E.). 

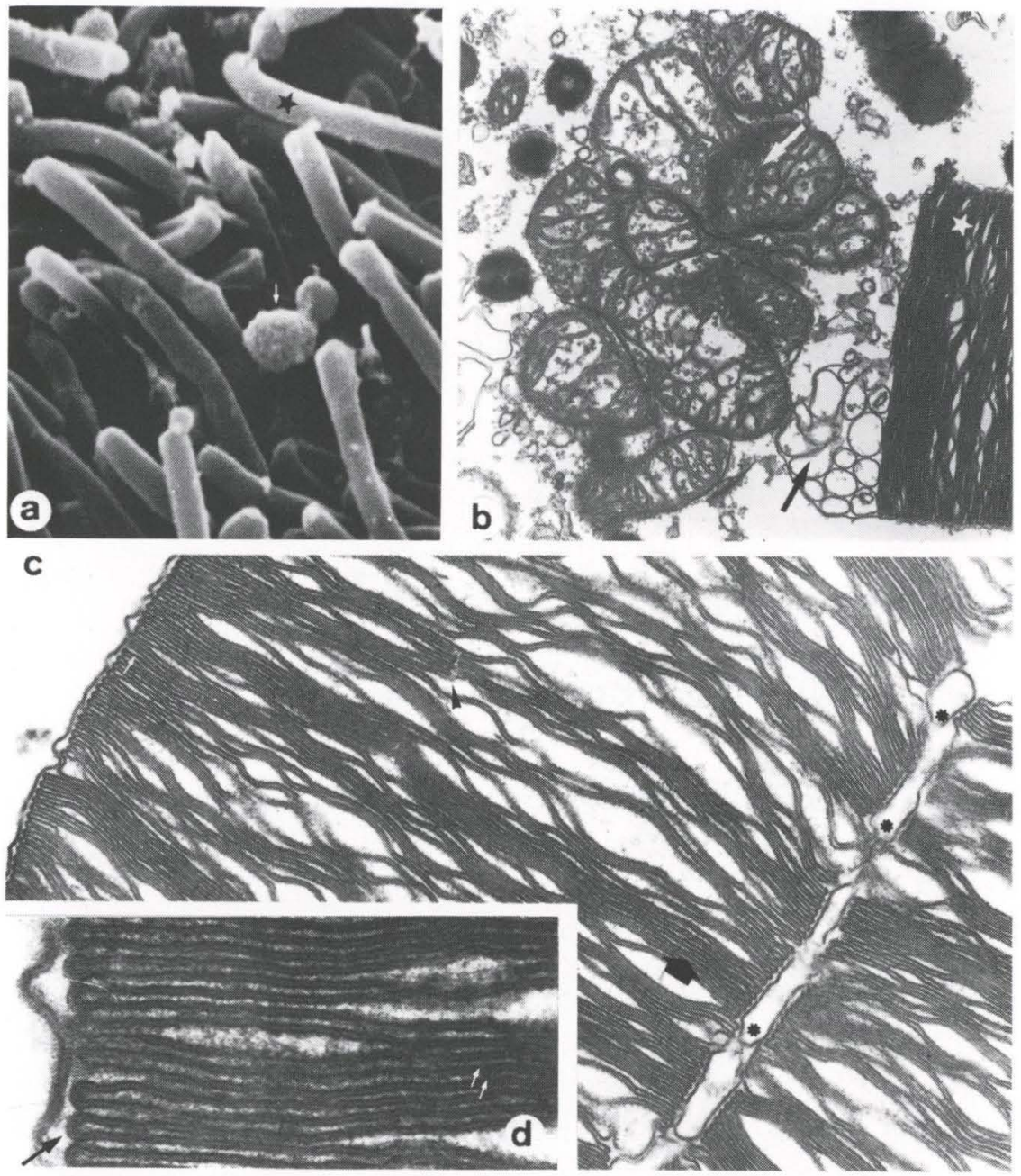

Fig. 9. (a) Cylindrical outer segments of rods (star) surrounded by some melanin grains (arrow) in Metynnis roosevelti (SEM). (b) Outer segment of rods (star), stalk (arrow) and concentration of mitochondria (white arrow) in the internal segment (TEM). (c) Detail of the membrane discs of the outer segment of rods. Notice the double membrane (small arrow), short discs (arrow head) and long discs (white arrow), and the connection between neighbour cells (star) (TEM). (d) Detail of (c) showing the lack of continuity with the extracellular space (arrow) and the double membranes surrounding each disc (small arrows) (TEM).

close to the outer limiting membrane to close to the plexiform layer (Figs 4c, 6). They are smaller than the nuclei of cones, very dense, drop shaped and with high affinity for haematoxylin. The pedicles are small with long lateral extensions.

The ratio between the number of cones and rods nuclei in the outer nuclear layer is $1: 2.50( \pm 0.22)$. 


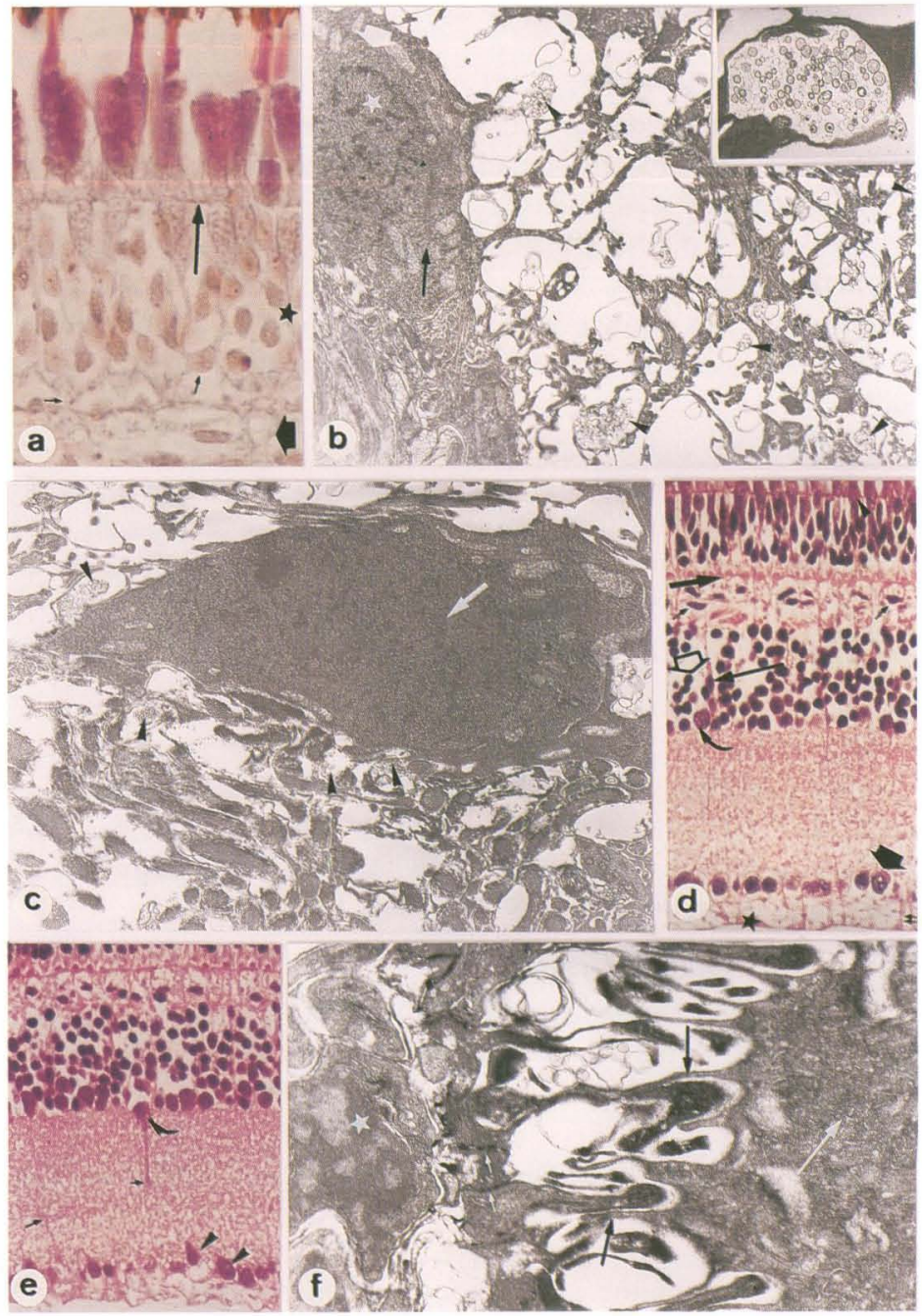

Fig. 10. (a) Outer nuclear layer (star) and outer plexiform layer (wide arrow) of the retina of Metynnis roosevelti. Notice the connections between the fibres of photoreceptor cells and neurones (arrows) and the region of zonulae adherens between Müller's cells and the inner segments of rods and cones (long arrow) (Novelli). (b) Inner plexiform layer, with extensions of bipolar, amacrine and ganglion cells with many synaptic vesicles (arrow heads) (detail in insert) and some extensions of ganglion cells with nucleus (star) and pericarion (arrow) (TEM). (c) Detail of multipolar ganglion cell with nucleus (white arrow), pericarion and synapses (arrow head) (TEM). (d) Cytoplasmic processes of Müller cells (double arrow) extending from inner limiting membrane till the outer limiting membrane. Notice the differences in shape and affinity to stain of ganglion cells nuclei (round arrow), bipolar (white arrow), horizontal (small arrow) and amacrine cells (round arrow) in the outer nuclear layer. (e) Notice the details of amacrine cells (round arrow), ganglion cells (arrow head) and synapses between neurones at the plexiform layer (arrow) (H.E.). (f) Horizontal cell (white arrow) with numerous dendrites (arrow), contact with pedicles of photoreceptors (white small arrow) and nuclei of photoreceptor cells (star) (TEM). 


\section{Interconnective neurones}

Besides the photosensitive cells, the retina is a complex matrix of different kinds of neurones. In the external plexiform layer there are the first synaptic contacts of the visual system, between photoreceptor cells, horizontal, and bipolar cells (Figs 4a-c, 10a-b). Various photoreceptors converge to each bipolar cell (Fig. 10a) and form neural networks.

Horizontal cells show a slightly flattened nucleus while bipolar neurones have spherical dense nuclei and amacrine neurones show a slightly lighter nucleus (Fig. 10d).

Cell processes and regions of synapses can be seen in the outer plexiform layer and the internal plexiform layer (Fig. 10b,d,e). The internal plexiform layer contains the synaptic interactions between bipolar and amacrine cells and ganglion cells. In this region many synaptic vesicles are observed as well as the extensions of the mentioned nervous cells (Fig. 10c-e). Ganglion cells are large multipolar cells with a spherical nucleus and nucleolus, and Nissl bodies in their cytoplasm (Fig. 10d,e).

\section{Supporting cells}

Müller's cells are supported by the basal lamina that forms the inner limiting membrane (Fig. 10d) and extend towards the outer limiting membrane where they make connection through cellular junctions with the photoreceptors (Fig. 10a). Their nuclei are placed in the outer nuclear layer (Fig. 10d).

\section{Retinal pigmented epithelium}

In $M$. roosevelti the pigmented epithelium lies between the choroid layer and the neural retina where the extensions of its cells reach the outer part of the inner segments of the rods and cones. Its colour is brown due to the presence of melanin (Figs 4, 5, 8).

The basal region of the epithelial cells is supported by the Bruch's membrane (Figs 4b, 11f,g) rich in collagen fibres. The epithelial cells are cylindrical (Fig. 4b). Close to the basal region of the cell, there are cellular junctions like desmossomes (Fig. 13b) and higher up, the cells touch neighbouring cells only at some points leaving bigger spaces between them (Figs $4 \mathrm{~b}, 1 \mathrm{~g}$ ). At the basal region a high concentration of mitochondria can be seen (Fig. 13b,c). The nucleus is elongated (Figs 4b, 13d). The apical region of the epithelial cells presents numerous very long processes that extend towards the inner segment of cones and rods (Figs 4b, 7a, 13a). tors cells.

Specialised junctions were not found connecting epithelial and photorecep-

The cytoplasm of the epithelial cells is replenished by numerous grains of melanin (Figs 11 b, 13a-d, 11g), of varied shapes. They seem to be synthesised in layers resulting in concentric lamellar aspect (Fig. 1lb). Melanin grains can migrate inside the cell, stimulated by light or darkness (Fig. 1 la). On darkness withdrawal is observed and the pigments of melanin are aggregated at the basal region of the epithelial cells, the external segments of the rods remaining exposed (Fig. 11d). In 

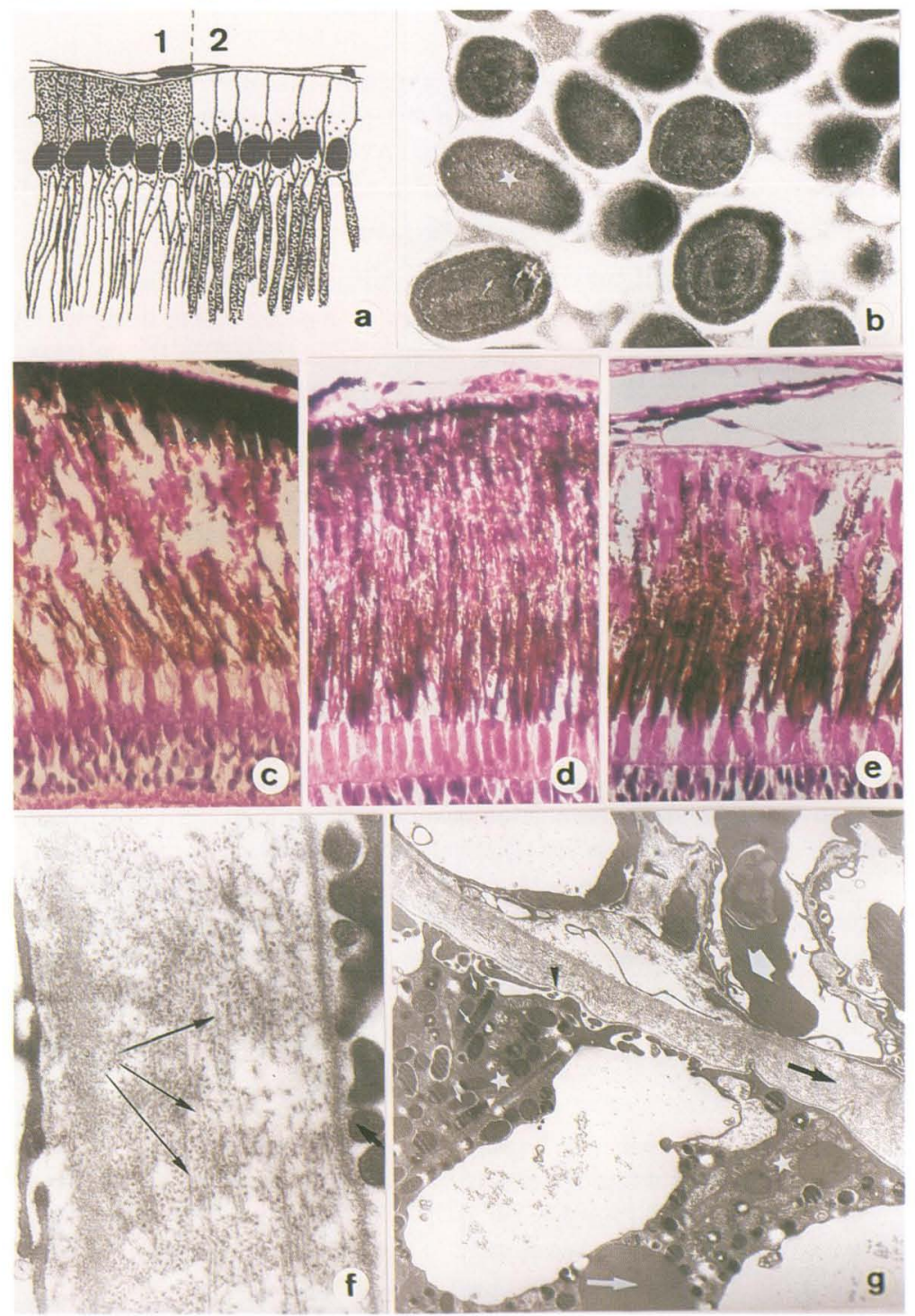

Fig. 11. (a) Schematic representation of the main position of melanin grains in the pigment epithelium cells of Metynnis roosevelti in darkness (1) and light (2). (b) Sectioned melanin grains (star) concentrated in the basal portion of the pigment epithelial cells. Notice their lamellar structure (arrows) (TEM). (c) Melanin grains concentrated in the basal region of the epithelial cells corresponding to the situation of darkness (H.E.). (d) Melanin grains migration to the apical region of epithelial cells when light period starts (H.E.). (e) Melanin grains concentrated in the medium and apical region of the cytoplasmic extensions of the epithelial cells, corresponding to light period (H.E.). (f) Bruch's membrane with collagen fibres (long arrow) and pigment grains of epithelial cells (short arrow) (TEM.). (g) Basal region of epithelial cells (star). Melanin grains (small white arrows) in various shapes, Bruch's membrane (black arrow), basal membrane (arrow head), blood vessel of choroid with red blood cell (white broad arrow), fat droplets (white arrow) (TEM). 
light, the movements are the opposite, expansion is observed and the melanin pigments enter the apical projections of the pigment epithelial cells, protecting therefore the external segments of the photoreceptors (Fig. 11e). These photomechanical movements occur gradually and all intermediate stages are observed during adaptation to light or dark conditions (Fig. 11d).

\section{Effect of the red light on the retina of Metynnis roosevelti}

No significant morphological changes on the size of the different layers of the retina or in the arrangement of the nervous cells as well as the structure of the photoreceptors or affinity of its cellular constituents to biological stains were observed when the retina was exposed to red light daily during the light period.

When red light treatment is started, the pigment expansion increases (Fig. $12 \mathrm{a}, \mathrm{g})$. In the control retinas exposed to day light this migration occurs slowly taking 8 hours for completion (Fig. 12i,j): at To the melanin pigments are distributed homogeneously in the pigment cells and after 8 hours the most part of the pigments is seen in the apical region (Fig. 12j). In red light the expansion of the pigments stops after four hours of exposure (Fig. 12c). Than a withdrawal occurs and after eight hours in red light the pigments are no longer concentrated in the extensions of the cells but are now concentrated in the basal region of the epithelial cells (Fig. $12 \mathrm{~d})$. Therefore, after eight hours in red light the characteristics are similar to those of a cell adapted to darkness (Fig. 11c) while after the same time, the control retina exposed to daylight, shows characteristics of adaptation to light (Fig. 11e). These photomechanical movements are observed day after day.

But a daily exposure to red light in all light periods, during one week, causes an increase in the renewal of the membrane discs of the rods. Therefore, more lamellae debris were phagocytosed by the pigmented epithelium cells. So, an unusual high number of pieces of membrane discs of the photoreceptors are seen inside the epithelial cells of retinas kept in red light (Fig. 13e,f).

\section{DISCUSSION}

Metynnis roosevelti are highly active fish that range over wide areas in tropical and sub-tropical regions and swim for considerable distances (MACHADOALISSON 1983; GÉRY \& FRANCE 1979). Therefore, they continuously face a high variable biotic and abiotic environment. They possess a complex behaviour that requires a complex visual system to face all situations.

They have relatively big eyes that show mobility, increasing their visual field what is useful for swimming and searching for food. It is expected that for high visual efficiency a retina with different photoreceptors like cones, for photopic vision, and rods, for scotopic vision, is needed (LEVINE \& MACNICHOL JR.1982; NICOL 1963; PAULUS et al. 1986; MUNK 1981, 1982) as well as a complex neuronal framework, such as seen in $M$. roosevelti.

The three types of cones in the retina of $M$. roosevelti, double cones, long single cones, and short single cones, are found in many other teleosts (NAG \& SUR 1992; AHLBERT 1969, 1976; FANTA et al. 1994; ENGSTRÖM 1960, 1963a,b) where their shape, size, and density differ among different species, being the single cones the basic type of photopic visual cell for all vertebrates (LYALL 1957). 

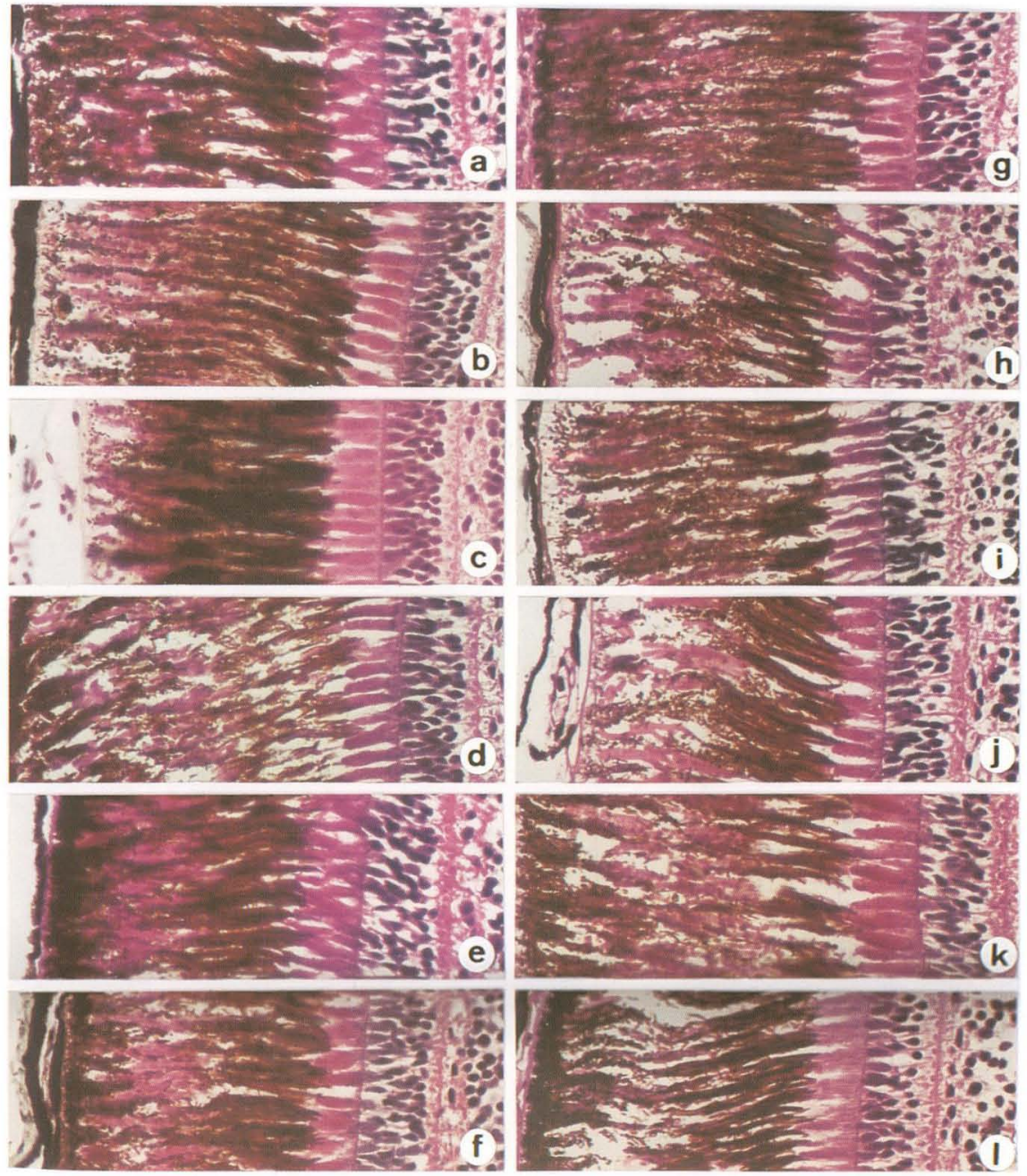

Fig. 12. (a-f) are experimental retinas exposed to red light; ( $g-1)$ are control retinas of Metynnis roosevelti exposed to daylight. (a) and (g): To; (b) and (h): 30 minutes after To; (c) and (i): 4 hours after To; (d) and (j): 8 hours after To; (e) and (k): 24 hours after To; (f) and (I): 48 hours after To. Notice the relative position of the pigments.

The relation between the presence of certain photoreceptor and the characteristics of the environment are not yet clear. Interspecific comparisons showed that some species that live in shallow waters, like $M$. roosevelti, have a mosaic of double and simple cones. On the other hand, some species that live in deep waters show only double cones, predominantly double cones, only single cones, or pure rod retinas (MunK 1981; ENGSTRÖM 1963a; LyALL 1957; BOEHLERT 1978).

Considering the ecology and the behavioural patterns of $M$. roosevelti, one can suggest that most certainly the presence of three different types of cones as well 

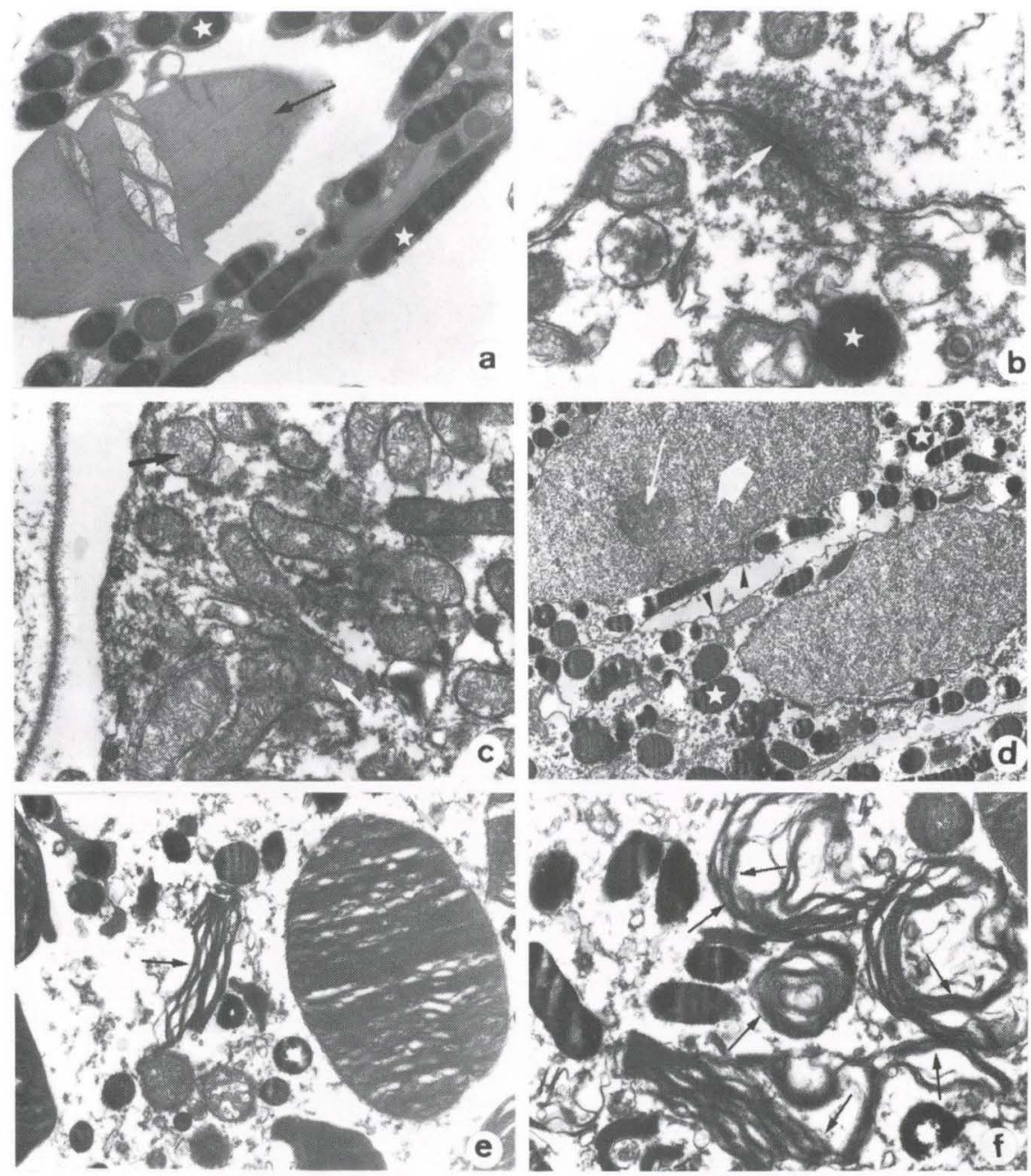

Fig. 13. (a) Detail of apical region of pigment cell of Metynnis roosevelti, rich in digitiform processes with melanin pigments (star) surrounding photoreceptor outer segments (arrow) (TEM). (b) Desmossomes (arrow) in the pigment epithelium of the retina joining two cells. Notice the mitochondria (star) (TEM). (c) Basal region of epithelial cell with mitochondria (arrows) (TEM). (d) Basal nuclei of epithelial cells (broad arrow) with nucleolus (arrow), melanin pigmentt (star) and cell membrane (white arrow) (TEM). (e) Detached membranes inside the epithelial cells (arrow) (TEM). (f) High number of piles of detached membrane discs (arrows) inside the epithelial cell (TEM).

as of rods is related to a wide range of perceptions not only of different wave lengths and luminosity but also of shapes, colours, and movements. As longer cones are considered to respond to longer wave lengths, and shorter cones to shorter ones (MUNK 1981), the retina of $M$. roosevelti will be able to respond to more or less the entire spectrum of wave lengths. From the evolutionary point of view this is a very 
positive characteristic as it allows high adaptability to unexpected situations, increasing the chances of survival.

The morphology of cones and rods is basically the same as for other fish species, but two special features were observed in the rods outer segment of $M$. roosevelti: discs of different diameters, with many groups of smaller discs and a connection between the plasma membrane of the outer segments. This last feature allows a communication between the cytoplasm of neighbour outer segments and possibly a functional co-ordination that, besides the presence of 2.5 times more rods than cones will probably improve the efficiency of perception of shapes and movements in low intensities of light. This factor explains their nocturnal activity. their vertical migrations, and the maintenance of school and it can also be advantageous for these fish when living in regions with a longer crepuscule, as occurs in the temperate regions of the southern Brazil, where it has been introduced.

In some species the dominating elements of the visual cell layer are the double cones (MUNK 1981). This is not the case for M. roosevelti where an equal number of double and long single cones are arranged as a parallelogram mosaic. The presence of different types of cones regularly displayed in the retina of these fish favours the spatial resolution of visual objects.

It is considered that the density of cones can indicate the level of perception of movements in all directions (KUNZ 1980; AHLBERT 1976; ROSSETO et al. 1992). The density of double cones in M. roosevelti is not as high as observed for some deep sea fish like Trachipterus trachypterus (MunK 1981), but its significance is not yet clear because some other deep water fish show only rods in their retinas. What is certain is that this density of three different types of cones and the presence of a higher number of rods contribute effectively to the quick visual reactions to the presence of food, or of other fish that is observed for M. roosevelti. It also allows migration and swimming for long distances in the nature.

Little is known of the functional relationship between the different types of ganglion cells but some topographic studies have been made. The giant ganglion cells described by these authors do not seem to exist in $M$. roosevelti except for the type 3 in the inner nuclear layer. The giant multipolar ganglion cells in M. roosevelti show metabolic activity, what can be seen by the presence of nucleoli and Nissl bodies, signifying effectiveness in sending messages to the optical nerve and to the brain.

Metynnis roosevelti has a conspicuous pigmented epithelium that occupies approximately one third of the visual retina. This is usefull for protection of the external segments of the rods, avoiding the bleaching of the photopigment present in this region, as is known for many other species as, for example Salmo gairdneri by DoUGLAs (1982). Not only the movements of retinal pigment as well as the displacement of cones and rods under the influence of light are called retinomotor movements and occur in many species (NICOL 1963), but in M. roosevelti only pigment movements were observed.

Metynnis roosevelti that lives in tropical and subtropical regions face low light intensity for a short time early in the morning with oblique light incidence. But at noon the light incidence is high. Therefore, if the expansion of the pigment starts 
as soon as luminosity starts and takes approximately eight hours to be complete, protecting the photosensitive segments this parallels the increase in light intensity in the nature.

Analysing the effect of monochromatic red light on the retina of $M$. roosevelti, compared to daylight, one can observe that no significant morphological changes occurred. But in red light there is a higher level of expansion of pigments to the apical region of epithelial cells, followed by a withdrawal of pigments to the basal region of the cells, where they are usually concentrated in the dark. This suggests that the migration may be elicited by the change from dark to light, at the start of the light period and not by the light quality. But then, as the light is composed only by long wave lengths, corresponding to red, this is perceived as relative darkness, causing the reversal of the process, making the pigment return to its dark-adapted position. On the other hand it is observed that the cells promote phagocytosis of a great amount of photosensorial membranes from rods when kept in such a regime for some days. This indicates a higher stimulation rate of the membrane discs resulting in increased speed of discs renewal, as the fish remain in darkness simulated by red light besides the usual night hours. The groups of piles connected by the plasma membrane that are eliminated seem to correspond to the portions where the cell membrane is not in communication with the neighbouring outer segment. Therefore, the wave length corresponding to the red colour is related to the adaptation to darkness.

Whether there is a limit or not for such a prolonged "darkness" is not certain, as far as the behaviour of the fish was not affected visibly in one week. Metynnis roosevelti continued normal behavioural patterns such as swimming, schooling and feeding. This result differs from that obtained for Oreochromis niloticus where a general decrease in the speed of all activities was observed (FANTA 1995).

Even originally from well illuminated regions close to the Equator (from $5^{\circ} \mathrm{N}$ to $\left.15^{\circ} \mathrm{S}\right) \mathrm{M}$. roosevelti show adaptive capacity to life in dark or variable environments, and to unusual photic conditions. This is particularly usefull, as this species has been recently not only used for fish cultures in tanks and aquariums, but also introduced in different southern regions (until $30^{\circ} \mathrm{S}$ ) where the photic regime is completely different from its place of origin. The complexity of its retina when compared to other species of fish and adaptability to varied light regimes increase their chances for positive natural selection.

ACKNOWLEDGEMENTS. The authors are indebted to Dr. M.A.H. Dolder and to Prof.Dr. R.L.Smith for their valuable suggestions; to MSc S.R.Grötzner for technical assistance in the preparation of the retinas; to the biologists A.C.C. Vianna and S. Romão for assistance in microphotography; to CAPES for a Master's stipend for Lucélia Donatti; to CNPq for a Scientist's stipend to Dr. Edith Fanta.

\section{REFERENCES}

AHLBERT, I.B. 1969. The organisation of the cone cells in the retinae of four teleosts with different feeding habits (Perca fluviatilis L., Lucioperca lucioperca L., 
Acerina cernua L.and Coregonus albula L). Arkiv. Zool., Stockholm, 22 (11): 445-481.

1976. Organization of the cone cells in the retinae of salmon (Salmo salar) and trout (Salmo trutta trutta) in relation to their feeding habits. Acta Zool., Stockholm, 57: 13-35.

Allen, E.E.; R.D. Fernald. 1985. Spectral sensitivity of the African cichlid fish, Haplochromis burtoni. Jour. Comp. Physiol., Heidelberg, 157A: 247-253.

BEÇAK, W.Y.; J.P. VANRELL. 1970. Técnicas de citologia e histologia. São Paulo, Ed. Nobel, 470p.

BoEHLERT, G.W. 1978. Intraspecific evidence for the function of single and double cones in the teleost retina. Science, Washington, 202: 309-311.

BÜCHERL, W. 1962. Técnica microscópica. São Paulo, Ed. Polígono, 164p.

CLARK, G. 1981. Staining procedures. Baltimore, Willians \& Wilkins, 512p.

Collin, S.P. 1993. The visual system of the florida garfish, Lepisosteus platyrhincus (Ginglymodi). Brain. Behav. Evol., Basel, 42: 295-320.

Culling, C.F.A.; R.T. Allison \& W.T. BARR. 1985. Cellular pathology technique. London, Butterworth, 642p.

DoUGLAS, R.H. 1982. The function of photomechanical movements in the retina of the rainbow trout (Salmo gairdneri). Jour. Exp. Biol., Cambridge, 96: 389-403. EAstMan, J.T. 1988. Ocular morphology in antarctic notothenioid fishes. J. Morphol., New York, 196: 283-306.

ENGSTRÖM, K. 1960. Cones types and cone arrangement in the retina of some cyprinids. Acta. Zool., Stockholm, 41: 277-295.

. 1963a. Cone types and cone arrangements in teleost retinae. Acta. Zool., Stockholm, 44: 179-243.

1963b. Structure, organization and ultrastructure of the visual cells in the teleost family Labridae. Acta. Zool., Stockholm, 44: 1-41.

FANTA, E. 1995. Influence of background colour on the behavior of the fish Oreochromis niloticus (Cichlidae). Arq. Biol. Tecnol., Curitiba, 38 (4): 1237 1251.

FAnTA, E.; S.R. Grötzner; M.F. LuvizotTo; M.L. Ishida \& L.M.P. WACHOWICZ. 1991. The environmental impact and the behavior of antarctic fish: I-Light. In: Abstracts of the SCAR International Conference on "Antarctic Science-Global Concerns", Bremen, 40.

Fanta, E.; A.A. Meyer; S.R. Grötzner \& M.F. Luvizotto. 1994. Comparative study on feeding strategy and activity patterns of two antarctic fish: Trematomus newnesi Boulenger, 1902 and Gobionotothen gibberifrons (Lönnberg, 1905) (Pisces, Nototheniidae) under different light conditions. Nankyoku Shiriô (Antarctic Rec.), Tokyo, 38 (1): 13-29.

GÉRY, J.; C.N.R.S. FrancE. 1979. The Serrasalmidae (Pisces, Characoidei) from the Serra do Roncador, Mato Grosso, Brasil. Amazoniana, Kiel, 6 (4): 467-495.

HAIRSTON JR., N.G.; K.T. Li \& S.S. EASTER JR. 1982. Fish vision and the detection of planktonic prey. Science, Washington, 218: 1240-1242.

KUNZ, Y.W. 1980. Cone mosaics in a teleost retina: changes during light and dark adaptation. Experientia, Basel, 36 (12): 1371-1374.

Levine, J.S. \& E.F. MACNichol JR. 1982. Colour vision in fishes. Sci. Amer., New 
York, 216 (2): 108-117.

LOUKASHKIn, A.S. \& N. GRANT. 1959. Behavior and reactions of the pacific sardine, Sardinops caerulea (Girard), under the influence of white and colored lights and darkness. Proc. Calif. Acad. Sci., San Francisco, 29 (15): 509-548.

LUFT, J.H. 1961. Improvements in epoxy resin embedding methods. J.Biophys. Biochem. Cytol., New York, 9: 409-414.

Lyall, A.H. 1957. Cone arrangements in teleost retinae. Q.J. Microsc. Sci., Cambridge, 98 (2): 189-201.

Machado-Allisson, A. 1983. Estudios sobre la sistematica de la subfamilia Serrasalminae (Teleostei, Characidae). Parte II. Discusion sobre la condicion monofiletica de la subfamilia. Acta. Biol. Venez., Caracas, 11 (4): 145-195.

MENEZES, N.A.; H.J. WAGNER \& M.A. AlF. 1981. Retinal adaptations in fishes from a floodplain environment in the central amazon basin. Rev. Can. Biol., Montreal, 40 (1): 111-132.

MunK, O. 1981. On the cones of the mesopelagic teleost Trachipterus trachypterus (Gmelin,1789). Vidensk. Medd Dan. Naturhist Foren., Copenhagen, 143: 101-111.

- 1982. Cones in the eye of the deep-sea teleost Diretmus argenteus. Vision Res., Oxford, 22: 179-181.

NAG, T.C. \& R.K. SUR. 1992. Cones in the retina of the catfish, Clarias batrachus (L). Jour. Fish. Biol., London, 40: 967-969.

NiCOL, J.A.C. 1963. Some aspects of photoreception and vision in fishes. Adv. Mar. Biol., San Diego, 1: 171-208.

OMURA, Y.; M. OGURI. 1991. Photoreceptor development in the pineal organ and the eye of Plecoglossus altivelis and Paralichthys olivaceus (Teleostei). Cell Tissue Res., Heidelberg, 266: 315-323.

Pankhurst, N.W.; J.C. Montgomery. 1989. Visual function in four antarctic nototheniid fishes. Jour. Exp. Biol., Cambridge, 142: 311-324.

Paulus, W.M.; V. HömberG; K. Cunningham; A.M. Halliday. 1986. Colour and brightness coding in the central nervous system: theoretical aspects and visual-evoked potentials to homogeneous red and green stimuli. Proc. R. Soc. Lond. B. Biol. Sci., London, 227: 53-66.

PogGiO, T. \& C. Koch. 1987. Synapses that compute motion. Sci. Amer., New York, 256 (2): 42-48.

REYNOLDS, E.S. 1963. The use of lead citrate at high $\mathrm{pH}$ as an electron-opaque stain in electron microscopy. Jour. Cell Biol., New York, 17: 208-212.

Rosseto, E.S.; H. Dolder \& I. SAZIMA. 1992. Double cone mosaic pattern in the retina of larval and adult piranha, Serrasalmus spilopleura. Experientia, Basel, 48: 597-599.

Samejima, M.; S. TAmotsu; Y. Muranaka \& Y. Morita. 1991. Dissociation of photoreceptor cells from the pineal organ of the lamprey, Lampetra japonica. Cell Tissue. Res., Heidelberg, 263: 589-592.

Teyke, T. \& S. Schaerer. 1994. Blind mexican cave fish (Astyanax hubbsi) respond to moving visual stimuli. Jour. Exp. Biol., Cambridge, 188: 89-101.

WATSON, M.L. 1958. Staining of tissue sections for electron microscopy with heavy metals. Jour. Biophys. Biochem. Cytol., New York, 4 (4): 475-478. 
WHEELER, T.G. 1979. Retinal red sensitivity under dark-adapted conditions. Brain Res. Rev., Amsterdam, 175: 140-144.

-1982. Colour vision and retinal chromatic information processing in teleost: a review. Brain Res. Rev., Amsterdam, 4: 177-235.

Williamson, M. \& A. KEAST. 1988. Retinal structure relative to feeding in the rock bass (Ambloplites rupestris) and bluegill (Lepomis macrochirus). Can. Jour. Zool., Ottawa, 66: 2840-2846.

ZAUNREITER, M.; H. JUNGER \& K. KOTRSCHAL. 1991. Retinal structure; physiology and pharmacology. Vision Res., Oxford, 31 (3): 383-394.

Recebido em 17.X.1997; aceito em 22.II.1999. 